\title{
Eruptive Pseudoangiomatosis in Adult Associated to Parvovirus B19
}

\author{
Soriano Maldonado Cristina ${ }^{1 *}$ and López de San Vicente Hernández Iranzu ${ }^{2}$ \\ ${ }^{1}$ Primary care physician, Primary Care Center of Muchamiel, San Juan de Alicante Department, Alicante, Spain \\ ${ }^{2}$ Primary care physician, Primary Care Center of San Adrian, Bilbao, Spain
}

*Corresponding author: Cristina Soriano Maldonado, Primary Care Center of Muchamiel, Calle del Mar, 0, 03110, Muchamiel

(Alicante), Spain

\begin{tabular}{l}
\hline ARTICLE INFO \\
Received: 幽 August 15, 2020 \\
Published: 幽 August 25, 2020 \\
\hline
\end{tabular}

Citation: Soriano Maldonado C, López de San Vicente Hernández I. Eruptive Pseudoangiomatosis in Adult Associated to Parvovirus B19. Biomed J Sci \& Tech Res 29(5)-2020. BJSTR. MS.ID.004850.

\begin{abstract}
Eruptive pseudoangiomatosis (EP) is a rare disease characterized by benign spontaneous regressing exanthema. It consists of the acute onset of small erythematous papules, similar to angiomas that disappear spontaneously. The etiology is still unknown, and it occurs commonly in children, but it has also been described in adults.

\section{Summary}

It presents a clinical case of a 56-year-old female, attended at the Primary Care Center in Muchamiel, Spain, with acute onset of pruritic erythematous papules lesions. Serological test showed parvovirus B19 acute infection and the biopsy confirms the diagnosis.
\end{abstract}

Keywords: Eruptive Pseudoangiomatosis; Parvovirus B19; Adults

\section{Introduction}

Eruptive pseudoangiomatosis (EP) is a rare disease characterized by benign spontaneous regressing exanthema of an unknown etiology. It consists of an acute onset of small eruption of distinctive erythematous angioma-like papules that are often surrounded by a pale halo [1-3]. Histologic findings show dilated dermal blood vessels with plump endothelial cells protruding into the lumen and mild-to moderate perivascular lymphohistiocytic infiltrates [4]. The etiology of this eruptive disease is still unknown. However, association with insect bites [5] and with ECHO virus, coxsackie B, Epstein-Barr virus and cytomegalovirus [6,7] have been described. We are reporting a case of a woman with this condition associated to parvovirus B19.

\section{Case Report}

A 56-year-old female patient visited our Primary Care center in July 2020. The current condition begins 24 hours prior to consult, with a generalized onset of $3-4 \mathrm{~mm}$ erythematous papules with a peripheral pale halo. Lesions were moderate pruritic, and they were located on her upper and lower extremities and trunk mostly (Figure 1) No systemic symptoms, including fever, were present. She had no history of upper respiratory tract infection and no medical problems. We took a skin biopsy and histopathological findings showed a mild superficial perivascular dermatitis. Laboratory findings revealed an acute Parvovirus B19 (IgM+). No other blood test findings were remarkable. Treatment was started with cetirizine $10 \mathrm{mg}$ per day and the lesions spontaneously disappeared after approximately 3 weeks. 


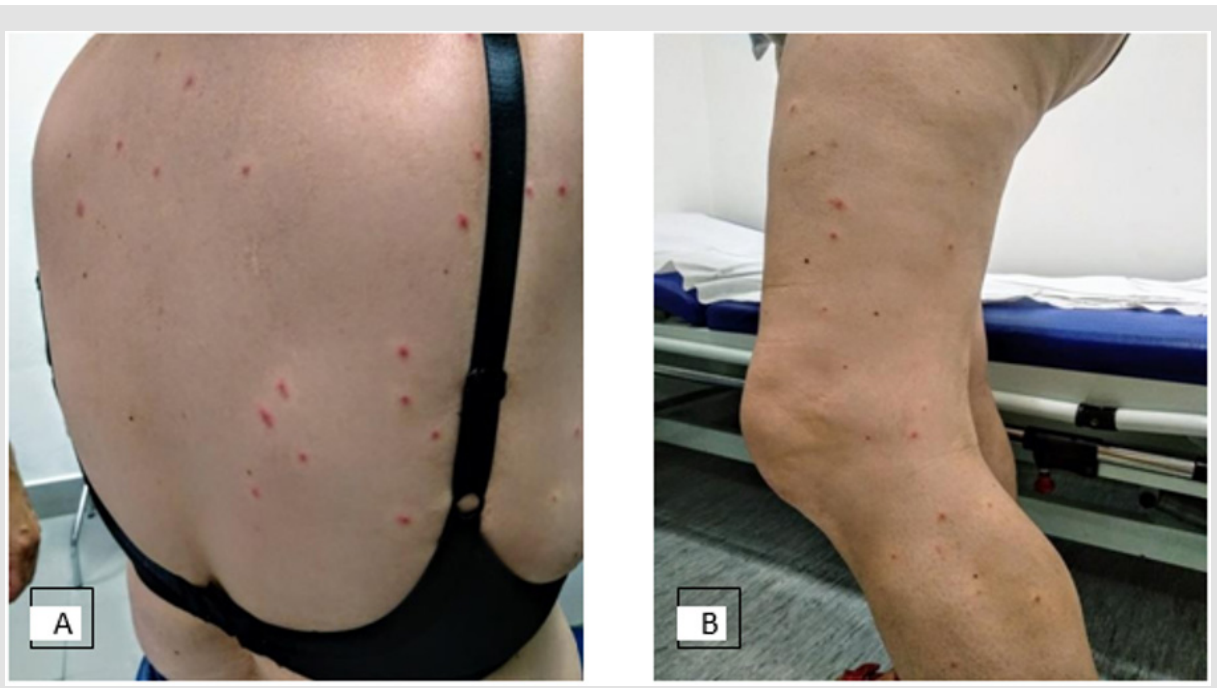

Figure 1:

A. Well-defined red papules with a perilesional blanched halo on the back and

B. on the lower extremities.

\section{Discussion}

EP usually presents as an erythematous papules with a perilesional pale halo that disappears in a few days. This illness is unusual and the exanthem eruption is usually asymptomatic or slightly pruritic $[2,8]$. The first time that this disease was described was in 1969 by Cherry et al in children with enterovirus-enteric cytopathic human orphan (ECHO) virus infection [1] and Navarro, et al. [6] described a case report with clinical evidence of EpsteinBarr virus (EBV) In 1993, as well as, Prose et al described an eruption with similar features in 3 children, but unfortunately could not confirm its origin [2]. It is usually overserved in childhood $[2,8]$, but in 2000, 10 cases were reported in Spanish adults, most of them in women [6,8]. In 2016, another case of a 73-year-old female was reported in Spain [9]. Recently, in 2018, 12 cases in adults were described from India by Chopra, et al. [10], who observed that females are more commonly affected. Our case report appears in summer, the same as the 7 cases described by Barrio, et al. [11]. The patient had no history of preceding symptoms. The onset of dermic lesions was 24 hours before consulting, which started from the extremities and spread to involve the trunk. The eruption was moderately pruritic. Multiple eruptive capillary hemangioma, viral exanthema, multiple pyogenic granuloma, popular urticaria or insect bites were considered in the differential diagnosis.

Histological findings show that epidermis is generally unaffected and there is no evidence of vascular proliferation; these findings justify the name of this disease: "eruptive pseudoangiomatosis" [2]. As we see in our patient, the clinical features and histological findings were similar to those described for EP. Its etiology is still unclear, however, most cases in the literature were related to viruses $[6,12,13]$ but the development of the disease has also been observed due to insect bites 5 and also in 2 subjects after taking an herbal medicine [13]. In our case report, we could perform a serology test and acute Parvovirus B19 infection was detected, which is first described in literature. Usually the family Parvoviridae doesn't affect humans, however, the only one that can be pathogenic in people is Parvovirus B19. On the one hand, immunocompetent individuals' immune system can control the infection, causing the erythema infectiosum (in children) and polyarthropathy (in adults). However, a pure red cell aplasia and chronic anemia can be caused in immunocompromised individuals [14]. Nevertheless, it has never been related to EP or to the onset of angioma-like lesions. There's no specific treatment for EP, however, oral antihistamines and topical steroids can decrease syntoms [10]. As in our patient who received oral antihistamines.

\section{Conclusion}

This is the first case described in literature where the Parvovirus B19 is detected as the main cause of eruptive pseudoangiomatosis in adults. Because of that, it is necessary to keep in mind that many types of virus infection could cause this disease and we need to look for them conscientiously through laboratory and serological tests. Our report highlights the importance of keeping on studying the etiology of this disease in order to detect silent diseases, so that, we suggest that more cases need to be studied.

\section{Funding Source}

No external funding for this manuscript.

\section{Financial Disclosure}

The authors have no financial relationships relevant to this article to disclose.

\section{Conflict of Interest}

The authors have declared no conflict of interest. 


\section{References}

1. Cherry JD, Bobinski JE, Horvath FL, George D Comerci (1969) Acute hemangioma-like lesions associated with echo viral infection. Pediatrics 44(4): 498-502.

2. Prose NS, Tope W, Miller SE, Hideko Kamino (1993) Eruptive pseudoangiomatosis: a unique childhood exanthema? J Am Acad Dermatol 29: 857-859.

3. Neri I, Patrizi A, Guerrini B, G Ricci, R Cevenini (2000) Eruptive pseudoangiomatosis. Br J Dermatol 143: 435-438.

4. Chuh A, Zawar V, Law M, Sciallis G (2012) Gianotti-Crosti syndrome, pityriasis rosea, asymmetrical periflexural exanthem, unilateral mediothoracic exanthem, eruptive pseudoangiomatosis, and papularpurpuric gloves and socks syndrome: A brief review and arguments for diagnostic criteria. Infect Dis Rep 4(1): e12.

5. Oka K, Ohtaki N, Kasai S, Takayama K, Yokozeki H (2012) Two cases of eruptive pseudoangiomatosis induced by mosquito bites. J Dermatol 39: 301-305.

6. Navarro V, Molina I, Montesinos E, Calduch L, Jordá E (2000) Eruptive pseudoangiomatosis in an adult. Int J Dermatol 39: 237-238.

7. Pitarch G, Torrijos A, García Escrivá D, Martínez Menchón T (2007) Eruptive pseudoangiomatosis associated to cytomegalovirus infection. Eur J Dermatol 17: 455-456.

ISSN: 2574-1241

DOI: 10.26717/BJSTR.2020.29.004850

Soriano Maldonado Cristina. Biomed J Sci \& Tech Res

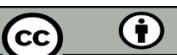

This work is licensed under Creative Commons Attribution 4.0 License

Submission Link: https://biomedres.us/submit-manuscript.php
8. Guillot B, Dandurand M (2000) Eruptive pseudoangiomatosis arising in adulthood: 9 cases. Eur J Dermatol 10(6): 455-458.

9. Alcántara Reifs CM, Salido Vallejo R, Garnacho Saucedo G, Rizo Barrios A, Garcla Nieto AV (2016) Asymptomatic angiomatous lesions on the face and limbs of an adult woman. Indian J Dermatol Venereol Leprol 82: 356-357.

10. Chopra Dimple, Sharma Aastha, Kaur Satwinder, Singh Ravinder (2018) Eruptive pseudoangiomatosis - cherry angiomas with perilesional halo. Indian J Dermatol Venereol Leprol 84(4): 424-430.

11. Pérez Barrio S, Gardeazábal J, Acebo E, Martínez de Lagrán Z, Díaz Pérez JL (2007) Eruptive pseudoangiomatosis: Study of 7 cases. Actas Dermosifiliogr 98: 178-182.

12. Venturi C, Zendri E, Medici MC (2004) Eruptive pseudoangiomatosis in adults: a community outbreak. Arch Dermatol 140: 757-758.

13. Jung J, Kim SC (2004) Eruptive pseudoangiomatosis: three cases in Korean middle-aged women. Acta Derm Venereol 84: 241-242.

14. Heegaard ED, Brown KE (2002) Human parvovirus B19. Clin Microbiol Rev 15: 485-505.

$\begin{array}{ll}\text { BIOMEDICAL } & \text { Assets of Publishing with us } \\ \text { RESEARCHES } & \text { - Global archiving of articles } \\ \text { - Immediate, unrestricted online access } & \text { - Rigorous Peer Review Process } \\ & \text { - Anthors Retain Copyrights } \\ \end{array}$

